\title{
Propylthiouracil-induced liver failure and artificial liver support systems: a case report and review of the literature
}

Dong-Bo $\mathrm{Wu}^{1,2}$

En-Qiang Chen ${ }^{1,2}$

Lang Bai ${ }^{1,2}$

Hong Tang ${ }^{1,2}$

'Center of Infectious Diseases, West China Hospital of Sichuan University,

${ }^{2}$ Division of Molecular Biology of Infectious Diseases, State Key Laboratory of Biotherapy, Sichuan University, Chengdu, People's Republic of China
Correspondence: Hong Tang Center of Infectious Diseases, West China Hospital of Sichuan University, 37 Guoxue Lane, Chengdu, Sichuan 61004I, People's Republic of China

Tel +8628 85423052

Fax +862885423052

Email htang6198@hotmail.com
This article was published in the following Dove Press journal:

Therapeutics and Clinical Risk Management

II January 2017

Number of times this article has been viewed

Background: Antithyroid drugs carry a potential risk of hepatotoxicity. Propylthiouracil (PTU) is commonly prescribed for patients with hyperthyroidism. PTU, however, can induce liver injury, ranging from mild asymptomatic elevation of aminotransferases to acute liver failure (ALF).

Case presentation: This case reports on a 16-year-old Chinese girl with hyperthyroidism, who was admitted to our hospital for jaundice, nausea, and fatigue associated with severe hyperbilirubinemia and coagulopathy. She had been prescribed PTU 5 months earlier. There was no history of hypersensitivity to drugs, viral liver diseases, blood transfusion, or surgery. On the basis of her symptoms and the clinical data, she was diagnosed with PTU-induced ALF. Due to the limited number of available donor organs for liver transplantation, she was started on treatment with artificial liver support system (ALSS). After four sessions of ALSS, her clinical signs and symptoms were found to be markedly improved, and she was discharged 25 days after admission. Four months later, her liver function normalized.

Conclusion: Although PTU-induced liver failure is rare in clinical practice, liver function should be appropriately monitored during treatment with PTU. PTU-induced ALF in this patient was successfully managed with an ALSS, suggesting that the latter may be an alternative to liver transplantation.

Keywords: propylthiouracil, liver injury, acute liver failure, artificial liver support systems

\section{Introduction}

Antithyroid drugs (ATDs), including propylthiouracil (PTU), methimazole (MMI), and carbimazole $(\mathrm{CBM})$, are the primary medical agents used to treat hyperthyroidism. ${ }^{1}$ PTU is commonly prescribed for patients with hyperthyroidism, especially for pregnant women during their first trimester. ${ }^{1}$ Drug-induced liver injury (DILI), ranging from mild asymptomatic elevation of aminotransferases to acute liver failure (ALF), ${ }^{2}$ however, has been observed in some patients treated with ATDs. This case report describes a patient with PTU-induced ALF, who was successfully managed with an artificial liver support system (ALSS), suggesting that the latter may be an alternative to liver transplantation.

\section{Case presentation}

A 16-year-old Chinese girl was admitted to West China Hospital of Sichuan University for the treatment of liver failure on 15 January 2015. A written informed consent was obtained from the patient's parent for the publication of this case report. Five months earlier, she had been diagnosed with hyperthyroidism (Grave's disease) at a local hospital 
and was prescribed PTU $50 \mathrm{mg}$ every 12 hours. Two weeks before admission to our hospital, after treatment with PTU for 4 months, she began to experience a change in urine color, decreased appetite, and increasing icterus of the sclera and skin. At admission to our hospital, her thyroid-stimulating hormone concentration was $0.025 \mathrm{mU} / \mathrm{L}$ (normal range, $0.27-$ $4.2 \mathrm{mU} / \mathrm{L}$ ), free triiodothyronine was $13.68 \mathrm{pmol} / \mathrm{L}$ (normal range, 3.6-7.5 pmol/L), free thyroxine was $92.33 \mathrm{pmol} / \mathrm{L}$ (normal range, 12.0-22.0 pmol/L), thyrotrophin receptor antibody was $19.98 \mathrm{IU} / \mathrm{L}$ (normal range, <3 IU/L), and ammonia concentration was $136 \mu \mathrm{mol} / \mathrm{L}$ (normal range, 9.0-33.0 $\mu \mathrm{mol} / \mathrm{L})$. Her hepatic function tests revealed a total bilirubin of $408.9 \mu \mathrm{mol} / \mathrm{L}$ (normal range, 5.0-28.0 $\mu \mathrm{mol} / \mathrm{L}$ ), direct bilirubin of $298.7 \mu \mathrm{mol} / \mathrm{L}$ (normal range, $<8.8 \mu \mathrm{mol} / \mathrm{L}$ ), alanine aminotransferase (ALT) of 130 IU/L (normal range, $<40 \mathrm{IU} / \mathrm{L}$ ), aspartate aminotransferase (AST) of $100 \mathrm{IU} / \mathrm{L}$ (normal range, <35 IU/L), alkaline phosphatase of 389 IU/L (normal range, 105-560 IU/L), gamma-glutamyl transpeptidase of $79 \mathrm{IU} / \mathrm{L}$ (normal range, $<45 \mathrm{IU} / \mathrm{L}$ ), total protein of $54.9 \mathrm{~g} / \mathrm{L}$ (normal range, $65.0-85.0 \mathrm{~g} / \mathrm{L}$ ), and albumin of $32.9 \mathrm{~g} / \mathrm{L}$ (normal range, $40.0-55.0 \mathrm{~g} / \mathrm{L}$ ). Coagulation tests showed a prothrombin time of 27.0 seconds (normal range, 9.6-12.8 seconds) and prothrombin time international normalized ratio of 2.35 (normal range, 0.88-1.15). She was negative for serum markers of hepatitis A, B, C, D, and E; human immunodeficiency virus; Epstein-Barr virus; cytomegalovirus; and for antibodies indicative of autoimmune hepatitis (antinuclear antibody, smooth muscle antibody, liver/kidney microsome type 1 , liver cytosol type 1 , soluble liver antigen, and antineutrophil cytoplasmic antibody) and primary biliary cirrhosis (antimitochondrial antibody). She had no history of drug hypersensitivity, liver diseases, blood transfusion, or surgery. She denied using over-the-counter and traditional Chinese medicines. She did not drink alcohol and did not use recreational drugs. Her medical history and family history were not contributory. Physical examination revealed that her temperature was $37^{\circ} \mathrm{C}$, blood pressure was 116/76 mmHg, pulse rate was 110 beats per minute, and breathing rate was 20 times per minute. She presented with severe icterus of the sclera and skin, but had experienced no disturbances in consciousness. Her thyroid was diffusely enlarged. Cardiovascular, respiratory, and abdominal examinations were normal. Ultrasound examination and computed tomography showed no obvious changes in her liver, pancreas, and spleen and no ascites. On the basis of these findings, she was diagnosed with PTU-induced ALF, without hepatic encephalopathy. PTU was discontinued, and medical treatment was started.

After 4 days of hepatoprotective treatment, she showed progressive worsening of itching, jaundice, and nausea, as well as deterioration in liver function, including total bilirubin $442.8 \mu \mathrm{mol} / \mathrm{L}$, direct bilirubin $350.7 \mu \mathrm{mol} / \mathrm{L}$, ALT $103 \mathrm{IU} / \mathrm{L}$, AST $186 \mathrm{IU} / \mathrm{L}$, total protein $49.7 \mathrm{~g} / \mathrm{L}$, and albumin $30.5 \mathrm{~g} / \mathrm{L}$. Owing to the limited number of donor organs available for liver transplantation, she was started treatment with ALSS. After four sessions of ALSS treatment, her clinical signs and symptoms were found to be improved, as the laboratory parameters showed (Table 1). Her total bilirubin level gradually improved to $122.1 \mu \mathrm{mol} / \mathrm{L}$, followed by improvements in symptoms by the time she was discharged 25 days after admission. Her liver function normalized after 4 months.

\section{Discussion}

More than 1100 drugs, herbal medicines, minerals, natural products, vitamins, dietary supplements, and recreational drugs have been found to cause DILI. ${ }^{3-5}$ In the USA,

Table I Biochemical parameters in the patient after each ALSS session

\begin{tabular}{|c|c|c|c|c|c|c|}
\hline ALSS session & $\begin{array}{l}\text { Total bilirubin } \\
(\mu \mathrm{mol} / \mathrm{L})\end{array}$ & $\begin{array}{l}\text { Direct bilirubin } \\
(\mu \mathrm{mol} / \mathrm{L})\end{array}$ & ALT (IU/L) & AST (IU/L) & $\begin{array}{l}\text { Bile acid } \\
(\mu \mathrm{mol} / \mathrm{L})\end{array}$ & $\begin{array}{l}\text { Ammonia } \\
(\mu \mathrm{mol} / \mathrm{L})\end{array}$ \\
\hline \multicolumn{7}{|l|}{ I (Day 5) } \\
\hline Before & 442.8 & 350.7 & 103 & 186 & 346.6 & 128 \\
\hline After & 205.9 & 158 & 53 & 100 & 277.5 & 55 \\
\hline \multicolumn{7}{|l|}{2 (Day 7) } \\
\hline Before & 343.6 & 254.2 & 82 & 187 & 321.4 & 56 \\
\hline After & 186.2 & 133 & 49 & 107 & 251 & 40 \\
\hline \multicolumn{7}{|l|}{3 (Day 9) } \\
\hline Before & 250.1 & 189.2 & 40 & 49 & 295.4 & 42 \\
\hline After & 129.8 & 97.5 & 23 & 30 & 236.6 & 58 \\
\hline \multicolumn{7}{|l|}{4 (Day I2) } \\
\hline Before & 224 & 163 & 24 & 39 & 229.6 & 60 \\
\hline After & 126.4 & 90.5 & 17 & 29 & 201.9 & 25 \\
\hline
\end{tabular}

Note: Normal range was $<10 \mu \mathrm{mol} / \mathrm{L}$ for bile acid.

Abbreviations: AST, aspartate aminotransferase; ALSS, artificial liver support system; ALT, alanine aminotransferase. 
DILI is the major cause of ALF, which can lead to liver transplantation and even death. ${ }^{3}$ The estimated incidence of ATD-associated hepatotoxicity ranges from $0.1 \%$ to $0.2 \%{ }^{6}$ PTU-induced hepatitis was first reported in 1947 in a patient who successfully recovered following drug discontinuation and supportive care. ${ }^{7}$ Six years later, the first case of PTU-induced liver failure was reported. ${ }^{8}$ Since then, these severe adverse events (AEs) have been observed in an extremely small number of patients receiving PTU. ${ }^{8}$ PTU-related AEs include rashes, leukopenia, arthritis, vasculitis, liver injury, and death, whereas MMI-related AEs include rashes, urticaria, arthralgias, vasculitis, and liver injury. ${ }^{9,10}$ PTU is able to inhibit the enzyme thyroperoxidase and block iodine organification. It also inhibits the enzyme $5^{\prime}$-deiodinase which converts thyroxine (T4) into the active triiodothyronine (T3). ${ }^{10}$

Approximately 15,000 adults per year are treated with PTU in the USA, with $\sim 0.1 \%$ experiencing PTU-induced severe liver injury. ${ }^{11}$ Another study evaluating 71,379 patients with hyperthyroidism in Taiwan found that the incidence of ATD-induced hepatitis was high, being 1.19/1000 personyears and 3.17/1000 person-years in patients treated with PTU and MMI/CBM, respectively. ${ }^{12}$ Moreover, treatment with high-dose $\mathrm{MMI} / \mathrm{CBM}$ was found to be associated with a 5.08-fold increased risk of hepatitis compared with any use of PTU. ${ }^{12}$ However, the risk of ALF was significantly higher in patients treated with PTU than MMI/CBM, with 1 of 17,688 patients requiring liver transplantation. ${ }^{12}$ The US Food and Drug Administration (FDA) has reported that of 32 patients (22 adults and 10 children) taking PTU who developed to ALF, 13 (12 adults and 1 child) died and 11 (5 adults and 6 children) required liver transplantation, whereas, of 5 adult patients taking MMI who developed to ALF, 3 died. ${ }^{13}$ It has been indicated that children appeared to be at higher risk for PTU-induced liver injury than adults. ${ }^{1,10}$ Although PTU has been recommended to women with hyperthyroidism during their first trimester of pregnancy, ${ }^{1}$ the FDA has described two pregnant women who experienced adverse effects of PTU treatment, ${ }^{14}$ and another case report described a 26 -year-old woman with PTU-associated ALF during her first trimester of pregnancy. ${ }^{15}$ Treatment with MMI, which is also frequently prescribed for patients with hyperthyroidism, can induce cholestatic hepatitis after drug exposure ranging from 2 days to 3 months. ${ }^{9}$

Although liver failure is associated with high morbidity and mortality rates, treatment options are limited. Orthotopic liver transplantation is the only ultimate treatment for patients with liver failure and end-stage liver disease, improving their overall survival rate. ${ }^{16}$ Owing to the limited number of donor organs available for liver transplantation, many patients die while on the waiting list. ALSS is developed to remove the water-soluble substances, lipophilic, and albumin-bound substances, thereby reducing recovery time from liver injury and serving as the bridge to liver transplantation. ${ }^{17,18}$ ALSS could significantly improve clinical manifestations, liver function, and 30-day survival rates in patients with acuteon-chronic liver failure. ${ }^{19}$ A case report described a patient with PTU-associated fulminant hepatic failure who was successfully managed with plasmapheresis. ${ }^{20}$ The ALSS used in this case was a plasma exchange (PE)-centered ALSS, which is widely applied in clinical practice across China according to the guidelines for artificial liver therapy. ${ }^{21}$ Our patient received four sessions of ALSS (including PE and plasma bilirubin adsorption) and conventional medical treatment. Her clinical parameters were markedly improved after each ALSS session, accompanied by decreased serum concentration of total bilirubin, direct bilirubin, ALT, AST, bile acid, and ammonia. However, a liver biopsy sample was not obtained owing to her parents' refusal. The classic histologic changes associated with PTU-induced hepatic injury include preserved liver architecture without evidence of advanced fibrosis and cirrhosis, chronic lobular hepatitis with cholestasis, and centrilobular necrosis. ${ }^{15,22}$ In summary, ATDs carry a potential risk of hepatotoxicity. Although PTU-induced liver failure is rare in clinical practice, liver function should be appropriately monitored during treatment with PTU, especially in the first 6 months of therapy, the period during which most cases of PTU-induced liver injury occur. Drug-induced ALF can be severe and even life-threatening, which may call for liver transplantation. Owing to the limited number of donor organs in China, ALSS may provide an alternative to liver transplantation for the treatment of PTU-induced liver failure.

\section{Conclusion}

Although propylthiouracil (PTU)-induced liver failure is rare in clinical practice, liver function should be appropriately monitored during treatment with PTU. PTU-induced acute liver failure in this patient was successfully managed with an ALSS, suggesting that the latter may be an alternative to liver transplantation.

\section{Acknowledgments}

This work was supported by Science and Technology Support Program of Sichuan Province, People's Republic of China (No 2015SZ0049).

\section{Disclosure}

The authors report no conflicts of interest in this work. 


\section{References}

1. Bahn Chair RS, Burch HB, Cooper DS, et al. Hyperthyroidism and other causes of thyrotoxicosis: management guidelines of the American Thyroid Association and American Association of Clinical Endocrinologists. Thyroid. 2011;21(6):593-646.

2. Sprague D, Bambha K. Drug-induced liver injury due to varenicline: a case report. BMC Gastroenterol. 2012;12:65.

3. Reuben A, Koch DG, Lee WM. Drug-induced acute liver failure: results of a U.S. multicenter, prospective study. Hepatology. 2010;52(6): 2065-2076.

4. Larrey D. Epidemiology and individual susceptibility to adverse drug reactions affecting the liver. Semin Liver Dis. 2002;22(2):145-155.

5. Mengual-Moreno E, Lizarzabal-Garcia M, Hernandez-Rincon I, Barboza-Nobrega Mde F. [Herbals and herbal nutritional products hepatotoxicity]. Invest Clin. 2015;56(3):320-335. Spanish.

6. Livadas S, Xyrafis X, Economou F, et al. Liver failure due to antithyroid drugs: report of a case and literature review. Endocrine. 2010;38(1): 24-28.

7. Livingston HJ, Livingston SF. Agranulocytosis and hepatocellular jaundice: toxic reactions following propylthiouracil therapy. J Am Med Assoc. 1947;135(7):422-425.

8. Eisen MJ. Fulminant hepatitis during treatment with propylthiouracil. N Engl J Med. 1953;249(20):814-816.

9. Zou H, Jin L, Wang LR, Braddock M, Cai WW, Zheng MH. Methimazole-induced cholestatic hepatitis: two cases report and literature review. Oncotarget. 2016;7(4):5088-5091.

10. Rivkees SA, Mattison DR. Propylthiouracil (PTU) hepatoxicity in children and recommendations for discontinuation of use. Int J Pediatr Endocrinol. 2009;2009:132041.

11. Carrion AF, Czul F, Arosemena LR, et al. Propylthiouracil-induced acute liver failure: role of liver transplantation. Int J Endocrinol. 2010; 2010:910636.
12. Wang MT, Lee WJ, Huang TY, Chu CL, Hsieh CH. Antithyroid drugrelated hepatotoxicity in hyperthyroidism patients: a population-based cohort study. Br J Clin Pharmacol. 2014;78(3):619-629.

13. Kuehn BM. FDA focuses on drugs and liver damage: labeling and other changes for acetaminophen. JAMA. 2009;302(4):369-371.

14. Glinoer D, Cooper DS. The propylthiouracil dilemma. Curr Opin Endocrinol Diabetes Obes. 2012;19(5):402-407.

15. Miyamura T, Kanda T, Minemura S, et al. Acute liver failure associated with propylthiouracil in a pregnant 26-year-old woman. Case Rep Gastroenterol. 2013;7(2):240-244.

16. Ostapowicz G, Fontana RJ, Schiodt FV, et al; U.S. Acute Liver Failure Study Group. Results of a prospective study of acute liver failure at 17 tertiary care centers in the United States. Ann Intern Med. 2002;137(12):947-954.

17. Struecker B, Raschzok N, Sauer IM. Liver support strategies: cutting-edge technologies. Nat Rev Gastroenterol Hepatol. 2014;11(3):166-176.

18. Podoll AS, DeGolovine A, Finkel KW. Liver support systems - a review. ASAIO J. 2012;58(5):443-449.

19. Du WB, Li LJ, Huang JR, et al. Effects of artificial liver support system on patients with acute or chronic liver failure. Transplant Proc. 2005;37(10):4359-4364.

20. Aydemir S, Ustundag Y, Bayraktaroglu T, Tekin IO, Peksoy I, Unal AU. Fulminant hepatic failure associated with propylthiouracil: a case report with treatment emphasis on the use of plasmapheresis. J Clin Apher. 2005;20(4):235-238.

21. 13th Asia-Pacific congress of clinical microbiology and infection consensus guidelines for diagnosis and treatment of liver failure. Hepatobiliary Pancreat Dis Int. 2013;12(4):346-354.

22. Chou C, Wong RJ, Higgins JP, Perumpail RB, Ahmed A. Acute liver failure: a potential complication of antithyroid medication use. Dig Dis Sci. 2015;60(7):1924-1927.
Therapeutics and Clinical Risk Management

\section{Publish your work in this journal}

Therapeutics and Clinical Risk Management is an international, peerreviewed journal of clinical therapeutics and risk management, focusing on concise rapid reporting of clinical studies in all therapeutic areas, outcomes, safety, and programs for the effective, safe, and sustained use of medicines. This journal is indexed on PubMed Central, CAS,

\section{Dovepress}

EMBase, Scopus and the Elsevier Bibliographic databases. The manuscript management system is completely online and includes a very quick and fair peer-review system, which is all easy to use. Visit http://www.dovepress.com/testimonials.php to read real quotes from published authors. 